Published as:

Gomez, F., Khawlie, M., Tabet, C., Darkal, A., Khair, K., and Barazangi, M., 2006. Late Cenozoic uplift along the northern Dead Sea transform in Lebanon and Syria, Earth Planet. Sci. Lett., 241, 913-931.

\title{
Late Cenozoic uplift along the northern Dead Sea transform in Lebanon and Syria
}

\author{
Francisco Gomez \\ Department of Geological Sciences, University of Missouri, \\ Columbia, Missouri 65211, USA \\ Mohamad Khawlie \\ Lebanese National Center for Remote Sensing, Beirut, Lebanon \\ Charles Tabet \\ Lebanese National Council for Scientific Research, Beirut, \\ Lebanon \\ Abdul Nasser Darkal \\ Department of Geology, Damascus University, Damascus, Syria \\ Kamal Khair \\ Department of Geology, American University of Beirut, Beirut, \\ Lebanon \\ Muawia Barazangi \\ Institute for the Study of the Continents, Snee Hall, Cornell \\ University, Ithaca, New York, 14853, USA
}

Corresponding Author:

Francisco Gomez

Department of Geological Sciences

101 Geological Sciences Building

University of Missouri - Columbia

Columbia, MO 65211

USA

Phone: 573-882-9744

e-mail: fgomez@missouri.edu 


\section{Abstract}

Evidence of long-term, late Cenozoic uplift, as well as strike-slip faulting, is revealed by topographic and geological features along the northern $500 \mathrm{~km}$ of the Dead Sea fault system (DSFS) - the transform boundary between the Arabian and African plates in the eastern Mediterranean region. Macro-geomorphic features are studied using a new, high-resolution (20 meter pixel) digital elevation model (DEM) produced by radar interferometry (InSAR). This DEM provides a spatially continuous view of topography at an unprecedented resolution along this continental transform from $32.5^{\circ} \mathrm{N}$ to $38^{\circ} \mathrm{N}$. This section of the left-lateral transform can be subdivided into a 200-km-long Lebanese restraining bend (mostly in Lebanon), and the section to the north (northwest Syria). Spatial variations in Cenozoic bedrock uplift are inferred through mapping of topographic residuals from the DEM. Additionally, high altitude, low-relief surfaces are mapped and classified in the Mount Lebanon and Anti Lebanon ranges that also provide references for assessing net uplift. These results demonstrate an asymmetric distribution of post-Miocene uplift between the Mt. Lebanon and Anti Lebanon ranges. Antecedent drainages also imply that an episode of uplift in the Palmyride fold belt post-dates uplift of the Anti Lebanon region. North of the restraining bend, the Late Miocene surface is preserved beneath spatially extensive lava flows. Hilltop remnants of this paleosurface demonstrate Pliocene-Quaternary uplift and tilting of the Syrian Coastal Range, adjacent to the DSFS north of the restraining bend. This late Cenozoic uplift is contemporaneous with strike-slip deformation along the DSFS. Geometrical relationships between folds and strike-slip features suggest that regional strain partitioning may accommodate a convergent component of motion between the Arabian and African plates. This interpretation is consistent with regional plate tectonic models that predict $10^{\circ}-25^{\circ}$ of obliquity between the relative plate motion and the strike of the DSFS north of the restraining bend. We suggest that this convergent component of plate motion is responsible for uplift along and adjacent to the DSFS in the Syrian Coastal Range, as well as within the Lebanese restraining bend.

Keywords: neotectonics, Dead Sea fault, continental transform, InSAR, DEM 


\section{Introduction}

The Dead Sea fault system (DSFS) is a globally prominent, continental transform that comprises a prominent tectonic element in the eastern Mediterranean region (Figure 1). Recent plate tectonic models have begun to suggest that the northern portion of this transform may be characterized as transpressional in nature. Recent studies have identified clear evidence of active tectonism along the DSFS, including paleoseismic indicators, for the main fault branches along the northern $500 \mathrm{~km}$ of the DSFS (i.e., north of approximately 32.5 $\mathrm{N}$ ) [1-5]. Results of these studies firmly refute recent assertions that the northern DSFS and the strike-slip faults in the Bekaa Valley are presently inactive [6, 7].

The availability of new databases allows the refinement and improvement of the knowledge and understanding of this tectonic system. To assess Pliocene-Quaternary tectonic signatures, this study constructed a high-resolution (20 meter pixel) digital elevation model (DEM) based on Synthetic Aperture Radar (SAR) interferometry, and incorporated this DEM with other remotely sensed imagery (e.g., Landsat TM, SPOT, ERS 1/2 SAR). The highest resolution DEM previously available spanning the entire region was the 90 meter pixel Shuttle Radar Terrain Mapper (SRTM) data set released in 2004. Hence, this DEM provides a continuous view of the topography along the northern DSFS at unprecedented resolution. With 20 meter pixels, detailed neotectonic features, such as fault scarps, can be clearly identified, and thus permit a more accurate mapping of fault zones and associated landforms. Furthermore, it has been demonstrated that morphometric parameters such as topographic slopes are underestimated by low resolution DEMs. Consequently, the new, higher resolution DEM may be more suitable for morphometric analyses that attempt to identify neotectonic signatures in the landscape.

The goal of this study is to document evidence for Late Cenozoic (post Miocene) uplift and provide additional constraints of long-term strike-slip displacements, along the northern DSFS. Part of this portion of the transform includes a large restraining bend where transpressional uplift is expected. We further suggest that uplift of the northwestern Syrian Coastal Range, a linear mountain chain parallel to the transform and located outside of the "Lebanese” Restraining Bend, also results from oblique plate convergence. We interpret that 
plate motions oblique to the transform result in regional strain partitioning between strike-slip faulting and folds parallel to the strike-slip faults.

\section{Tectonic setting}

The DSFS consists of three main sections (Figure 1) [8-10]: A 400-km-long southern section from the Gulf of Aqaba through the Araba, Dead Sea, and Jordan River Valleys; a 200km-long northeast-southwest striking restraining bend through the Mt. Lebanon and Anti Lebanon ranges, and a 250-km-long, north-south striking section in northwestern Syria and southern Turkey. This study focuses on the latter two sections of the transform, herein referred to as the northern DSFS.

The present-day relative motion between the Arabian and African plates is estimated to be 4 - $8 \mathrm{~mm} / \mathrm{yr}$, based on plate tectonic models and recent GPS observations [11-13]. This range of slip rates is consistent with results from field studies along the DSFS [1-3, 14]. There is a general agreement that movement on the DSFS has comprised two distinct episodes, although there are debates about the precise timing $[9,15,16]$. The first probably occurred during the Middle and Late Miocene, with 60 km of left-lateral displacement documented along the southern DSFS. The magnitude of slip on the northern DSFS during this time is unknown owing to a lack of confident piercing points of sufficient age, and some have suggested that the northern DSFS may have traced offshore during this time [17]. The second episode of motion began in the early Pliocene, probably corresponding with the "ridge push" from the onset of sea-floor spreading in the Red Sea [15], and this tectonic system persists through recent times. The total displacement on the southern and northern sections during this later episode are estimated at 45 $\mathrm{km}$ and 20 - $25 \mathrm{~km}$, respectively [9, 16] - much of the difference in displacement may be accommodated by up to $20 \mathrm{~km}$ of crustal shortening of the southwestern Palmyride fold belt [18].

The 200-km-long restraining bend encompassing present-day Lebanon and southwestern Syria (herein called the "Lebanese Restraining Bend" [LRB]) contains two subparallel mountain chains, the Mount Lebanon and Anti Lebanon ranges, with the intervening Bekaa Valley (Figure 1). Within this restraining bend, the relatively simple structural expression of the DSFS branches into several distinct strike-slip faults cutting through the mountain chains, including the Yammouneh, Serghaya, Rachaya, Hasbaya, and Roum faults [19]. Of these fault 
splays, the Yammouneh fault appears to be the only through-going structure connecting the southern and northern DSFS. The Serghaya fault cuts obliquely through the Anti Lebanon mountains and may link with the Palmyride fold belt $[1,19]$. The Roum fault appears to terminate into the Lebanese coastal flexure as a lateral ramp structure [20]. At the northern end of Mt. Lebanon, the Akkar fault also appears to link the coastal monocline with the main DSFS (Figure 1). Along the Akkar fault, the bedrock of the Mt. Lebanon rests in fault contact with late Neogene lavas [21] (discussed in more detail later).

The Palmyride fold belt (PFB) is another prominent tectonic element that has developed adjacent to the central DSFS (Figure 1). The PFB is a Mesozoic rift system that was subsequently inverted during the Cenozoic [18, 22]. Cross-section balancing [18, 23] suggests approximately $20 \mathrm{~km}$ of NW-SE horizontal shortening in the western Palmyrides compared with only 1 - $2 \mathrm{~km}$ of shortening in the eastern end of the fold belt. Although the growth of the structures initiated in the mid Cenozoic, interpretations of seismic reflection and well log data [17] and folded Neogene strata and Miocene lavas [23, 24] imply that the Palmyrides experienced a major episode of folding during the late Neogene. Quennell [9] also interpreted the topography of the Palmyrides to be of late Cenozoic landforms.

The northern DSFS follows a relatively simple and narrow trace between the Syrian/Lebanese border and the Ghab Valley in northwestern Syria (Figure 1). The Ghab Valley is a large strike-slip basin with up to 3.5 - $4 \mathrm{~km}$ of Pliocene and Quaternary fill [25, 26]. From the Ghab Valley northward, the northern DSFS involves several distinct fault splays as it traces through the Kara Su Valley and approaches the junction with the East Anatolian fault (Figure 1).

In addition to the DSFS and the Palmyride fold belt, late Neogene and Quaternary alkali volcanism is also characteristic of the Arabian plate adjacent to the DSFS [27]. Timing of volcanism varies spatially, from the late Miocene and early Pliocene in western Syria and northern Lebanon to the late Quaternary and Holocene in SW Syria [27, 28].

\section{DEM production}

One of the basic data sets for this study is a new, 20-meter pixel digital elevation model (DEM) constructed using interferometric synthetic aperture radar (InSAR). 14 pair of SAR images (i.e., 28 scenes) were used to construct the DEM (Figure 2a). Raw SAR data from the 
ERS 1 and ERS 2 satellites were selected with perpendicular baselines between $50 \mathrm{~m}$ and $350 \mathrm{~m}$. All but one of the pair were tandem pair (i.e., one-day between image acquisitions); the other image pair had a 70 day period between images. As expected, the tandem imagery, in general, showed a high degree of interferometric correlation, whereas the 70 day temporal baseline showed considerable decorrelation in basin areas, most likely a result of seasonal changes in vegetation and soil moisture.

The rugged topography of Lebanon and coastal Syria, in particular, posed a challenge to InSAR processing owing to geometric effects such as foreshortening and layover. Consequently, both ascending and descending orbits (providing WNW and ENE radar viewing geometries, respectively) were selected in overlapping areas in order to image topography that was masked by these effects in one view or the other.

Processing of the raw SAR data was accomplished using the Gamma Remote Sensing suite of radar processing software. Multi-looking at 1 sample in the azimuthal direction and 5 samples across track yielded an approximate ground resolution of 20 meters. A 90 meter DEM, available at Cornell University, was used for ground control in estimating precise baselines and geocoding the SAR image products. The precise baselines permitted the final conversion of the interferometric phase into a height map. Individual DEM segments were assembled into a single DEM using tools we developed with the ARC/INFO geographic information system (GIS).

This new DEM served as a base for regional geomorphic mapping. Based on the DEM, synthetic stereoscopic views were created, from which geomorphic features, such as low relief surfaces, could be identified and mapped. Key results of this interpretation and mapping are presented and discussed below.

\section{Topographic residuals and relief}

This study also used the DEM to provide a first-order view of spatial variations in topographic relief along the DSFS. Fundamental morphometric parameters of topography, (including the topographic slope gradient (Figure 2b), the slope azimuth, and the curvatures) were calculated from the DEM. These properties are typically determined from the DEM by attempting to fit a polynomial function to the elevation values within a relatively small window (3 pixels by 3 pixels, in this case). 
Hydrographic and ridgeline networks were also extracted from the DEM. Extracting the drainage network, involved filling of artificial sinks, calculation of flow direction and flow accumulation, and mapping "channels" based on an accumulation threshold -- all of these steps are standard in many Geographic Information System (GIS) and hydrological modeling software packages. In a related fashion, interfluves (ridgelines) were also extracted from the DEM.

Across the entire study area, relief was assessed through the mapping of "topographic residuals” [29]. A topographic residual map is constructed by taking the difference between the surface tangent to the interfluves (the "envelope" surface) and the hypothetical surface eroded to the level of the streams (the "subenvelope" surface) [29]. Elevation data points for each surface are determined using the ridge and stream networks extracted from the DEM. Each surface is contoured using a krigging algorithm, and, in the final step, the subenvelope surface is subtracted from the envelope surface.

A topographic residual map depicts the fluvial incision of the landscape, which depends upon tectonic activity / base level variations, bedrock lithology, and climate / vegetation. In regions of uplift, such as transpressional areas along the San Andreas fault in southern California, greater topographic residuals have been demonstrated to correspond with greater bedrock uplift [30, 31].

Both the Mount Lebanon and Anti Lebanon ranges demonstrate high topographic residuals (Figure 3b), but the magnitudes of relief are generally greater in the Mount Lebanon than in the Anti Lebanon. To a first order, the relief is a minimum estimate of late Cenozoic uplift. However, the differences in relief reflects, in part, the climate differences between the wetter Mount Lebanon region (mean precipitation $~ 800 \mathrm{~mm} / \mathrm{yr}$ ) and drier Anti Lebanon region (mean annual precipitation $\sim 400 \mathrm{~mm} / \mathrm{yr}$ ), as well as different base levels: The Anti Lebanon drains to base levels in the Bekaa Valley and Arabian platform ( $\sim 00$ meter elevation), whereas the Mount Lebanon drains to sea level. Consequently, one would expect that equivalent uplift of both ranges could produce less relief in the Anti Lebanon.

Two profiles (Figure 4) depicting the surfaces of the topography, envelope, and subenvelope further demonstrate the differences between the Mount Lebanon and Anti Lebanon. Broad regions along these profiles where the enveloping surface is nearly equal to the average topography (e.g., at the crest of the Mount Lebanon range) correspond with possible relict, lowrelief surfaces discussed below. 
The spatial distribution of topography and topographic residuals within the Lebanese restraining bend also suggests a general antisymmetry of bedrock uplift: In the Anti Lebanon, topography and residuals are greatest in the south, around Mt. Hermon, whereas the topography and topographic residuals in the Mount Lebanon are greatest in the north (Figure 3). Low and medium topographic residuals in the Palmyride fold belt (Figure 3) suggest that bedrock uplift is considerably less during the late Cenozoic than compared with the Mount Lebanon and Anti Lebanon ranges.

Topography along the northern DSFS is very asymmetric, with the Syrian Coastal Range confined primarily to the western block of the DSFS. Topographic profiles and residuals (Figures 5b and 6) demonstrate that relief in the Syrian Coastal Range contrasts with minimal relief east of the DSFS. Early Pliocene lava flows indicate that the surface east of the DSFS corresponds with the late Miocene surface - hence, this region has experienced minimal deposition or erosion.

\section{Expressions of uplift}

\subsection{Neogene paleosurface and uplift along the restraining bend}

Low-relief, high altitude surfaces may represent elements of relict landscapes that remain relatively unaffected by the present-day base level conditions. When they can be regionally correlated and reconstructed, these surfaces constrain magnitudes and spatial patterns of longterm uplift (e.g., [32, 33]).

Based on the DEM we identified and mapped high-altitude, low-relief surfaces, which may indicate late Cenozoic uplift along the DSFS. The recognition of these high-level relict surfaces in the study area was primarily based on concordance of low-relief summit regions and broad interfluves. Stereo interpretation was further assisted by a classification algorithm that identified continuous areas (greater than $5 \mathrm{~km}^{2}$ ) of low slope (less than 5 degrees), low profile curvature, bedrock outcrop (i.e., distinct from a quaternary depositional surface). Not surprisingly, these areas generally correspond with regions of low topographic residual, although all areas of low residual do not necessarily correspond with these paleo-surfaces. These criteria were similar to those applied in constructing a morphometric “summit level” map (e.g., [34, 35]). Small, continuous patches of surface were identified, and these patches were classified into groups based on topographic accordance of adjacent patches. 
Similarly, Quennell [36] identified erosional surfaces using numerous, adjacent topographic profiles along the southern portion of the DSFS. In that study, he identified a widespread erosional surface, termed the "Arabian" surface at a mean elevation of 800 meters in present-day Israel, Palestine, and Jordan. Subsequently, this surface was mapped to include the Tyre-Nabatiyeh plateau in Lebanon and parts of northern Syria [9]. Lacking more rigorous constraints, Quennell proposed a general Miocene age for this surface based on the ages of subsequent volcanism. Butler et al. [28] provided additional radiometric age constraints to suggest Late Miocene age for this surface in northern Lebanon.

Our study identified an extensive, high altitude, low-relief surface atop the Mount Lebanon and Anti Lebanon ranges (Figure 3b). The regional extent, i.e., covering significant areas of the Mount Lebanon and Anti Lebanon regions, suggests that this surface (warped and tilted in some locations) was originally a sub-horizontal datum. We suggest that this highaltitude, low-relief surface may also correspond with Quennell's Arabian surface. Along the southeastern flank of the Anti Lebanon, this interpretation is supported by the correspondence of the Neogene unconformity with the paleosurface [24]. This surface truncates upper Cretaceous strata in the Mount Lebanon (Figure 7) and across Cretaceous and Eocene strata in the Anti Lebanon [24]. Outside the LRB, the late Miocene and Pliocene lava flows also preserve remnants of a low relief, late Neogene surface.

Low relief regions in the Mt. Lebanon generally tilt 5 - 10 degrees westward, and this surface attains elevations of approximately 2,800 meters in the northern part of the Mt. Lebanon. In the southern Mt. Lebanon, the topography is lower in elevation, and the surface is not as well preserved as in the north.

In the northern Anti Lebanon, this surface is broadly warped, reflecting the general anticlinorium structure of the Anti Lebanon. At the southern end of the Anti Lebanon, the paleosurface is not preserved around Mt. Hermon - also where topographic residuals were greatest within the Anti Lebanon. The southern Anti Lebanon is disrupted by multiple strike-slip faults, and the Mt. Hermon block is probably more intensely uplifted.

Expressions of Quaternary folding and uplift can be found along the western margin of the Mount Lebanon. One noteworthy example is observed along the northern Lebanese coast, near Tripoli, in Jebel Turbol and the Jaouz anticline (Figure 8). The low-relief surface corresponding with the 700 ka marine terrace [37] has been folded. Cemented Quaternary sands 
and gravels (beach and near-shore deposits) cover an erosional surface beveled Miocene strata, and this erosional surfaced is folded into the Jaouz anticline. The unfolded portion of this surface is presently at an elevation of $\sim 120$ meters above present sea level - considering that the $700 \mathrm{ka}$ high sea level was similar to that of today, this suggests a long-term uplift of the Lebanese coast of $0.14 \mathrm{~mm} / \mathrm{yr}$. The Jaouz anticline demonstrates that local uplift rates along smaller structures has been even greater. The youth of the Jaouz anticline is suggested by the relative lack of channel incision and the correspondence of this surface with a late Quaternary unconformity [21]. As shown in Figure 8, the Abu Ali River deflects away from the northeastern end of the anticline, and older, abandoned channels of the Abu Ali River are apparent in the landscape and surficial geology [21]. From air photos and 1:20,000 topographic maps, the depth of incision of the present headwaters of Channel 2 (Figure 8) near the front of the Mount Lebanon appears continuous with the uppermost terrace level in the present-day Abu Ali river where it exits the Mount Lebanon. This relationship suggests the existence of a wind gap. Hence, there may be an apparent northeastward sense of "younging" of the channels, possibly indicating a northeastward propagation of the fold. This is similar to other well-documented propagating folds such as the Wheeler Ridge anticline in California [38]. This suggestion can be tested with future geological dating.

Our inference of Late Cenozoic uplift in the Mount Lebanon and Anti Lebanon contrasts with previous interpretations that the Mount Lebanon monocline is an old physiographic feature [39]. Walley [39] supported this interpretation by citing Neogene marine strata that appear to onlap the folded Mesozoic strata north of Beirut. However, these marine strata are locally tilted westward [21], which, in itself, is evidence of post-Miocene deformation. Our inferred paleosurface may serve as further evidence of Late Cenozoic uplift and deformation within the Lebanese Restraining Bend, particularly as it may illustrate spatial patterns of uplift: Uplift of this paleo-surface is greater in the Mt. Lebanon than in the Anti Lebanon, which is consistent with relative bedrock uplift interpreted from the pattern of topographic residuals.

\subsection{Antecedent drainages and the Palmyride fold belt}

Regional landscape features also permit assessing the relative timing of the Palmyride fold belt with respect to the Anti Lebanon. Specifically, antecedent drainages flow eastward from the Anti Lebanon through the western Palmyrides (e.g., Barada River) (Figure 9). The tilted and folded Neogene conglomerates incised by these rivers suggest that the rivers are 
antecedent to the folding, rather than simply superposed onto the structure. The eastward, inland flow of these antecedent drainages (as opposed to flowing westward to the Mediterranean Sea) implies that the Anti Lebanon region had been a topographic high prior to the main uplift of the western Palmyrides. Hence, a major pulse of uplift and folding of the Palmyride fold belt appears to have also occurred during the Late Cenozoic, after the Anti Lebanon / Mount Lebanon ranges began to serve as a topographic drainage divide.

\subsection{Post-Miocene uplift of the Syrian Coastal Range}

In contrast to the Mount Lebanon and Anti Lebanon, the late Miocene paleo-surface in the Syrian Coastal Range is, in general, not well preserved. The landscape is characterized by narrow ridges, with moderate to high relief. However, the Miocene surface is locally well preserved beneath hilltop remnants of the Pliocene basalt (Figure 10). A geological cross section across the southern Syrian Coastal Range and the DSFS (Figure 11a), shows that this paleosurface has been uplifted and tilted -- immediately west of the DSFS, it is now 500 meters above the corresponding surface east of the fault. Near the fault, this surface is tilted up to 15 degrees (Figure 11a). Based on this relationship, a long term uplift rate adjacent to the fault of less than $0.1 \mathrm{~mm} / \mathrm{yr}$ can be estimated, as well as an overall tilting rate of 3 degrees/myr. This evidence of long-term uplift is also consistent with studies of Holocene shorelines along the Syrian coast, which suggest $\sim 1.2$ meters of uplift during the past 6,000 years [40, 41].

The angle of unconformity between the lavas and the underlying Cretaceous bedrock varies from being $~ 5$ degrees near the DSFS to approximately conformable near the coast. Immediately north of the LRB, in the low relief region locally known as the "Homs Gap”, strata in the Syrian Coastal Range have been tilted considerably - maximum dips of about 5 degrees near the DSFS are observed (Figure 10). This lesser structural relief is mimicked by the lower topographic relief.

\section{Constraints on strike-slip displacements}

Prior studies have remarked on strike-slip landforms in the LRB (e.g., [10]) and along the DSFS in northwestern Syria (e.g., [5]). In this study, we discuss several specific observations from our mapping that provide additional constraints on the timing and magnitudes of late Neogene and Quaternary strike-slip displacements. 


\subsection{Strike-slip faulting in the Lebanese restraining bend}

In southern Lebanon, the $\sim 4 \mathrm{~km}$ deflection of the Litani river (incised $~ 100$ meters) at the Yammouneh fault has often been cited as a possible long-term marker (e.g., [42]). In general, however, caution should be exercised when inferring strike-slip displacements from a single deflection, such as this, owing to intrinsic uncertainties involved with meandering river patterns.

Strengthening this interpretation, our analysis of the DEM and imagery reveals a consistent suite of offset landforms along the Yammouneh fault in the southern Bekaa Valley (Figure 12a). This includes the $\sim 4 \mathrm{~km}$ deflection of the Litani River, as well as a series of wind gaps and deeply notched ridges east of the Yammouneh fault. All four of these notched ridges can be restored by a similar magnitude of displacement to match deep drainages emerging from Jebel Niha (Figure 12b). The abrupt change in the drainage pattern of the Litani River suggests that the southernmost ridge notch (Ridge A in Figure 12a) may have marked the previous course of the Litani River. When this course was abandoned in favor of the present, both were progressively offset by the Yammouneh fault -- hence the similar displacements. Westaway [42] inferred that the Litani River offset initiated $\sim 870 \mathrm{Ka}$, corresponding with regional fluvial incision in the northern Arabian platform and eastern Turkey [43]. The correlation of the Litani River incision with this inferred regional event was based on similar magnitudes of entrenchment of the Orontes River in northernmost Lebanon and northwestern Syria [44]. This correlation suggests a mean Quaternary slip rate of 4 - $5 \mathrm{~mm} / \mathrm{yr}$ for the Yammouneh fault.

In the Anti Lebanon range, river valleys demonstrate consistent leftward deflections along the entire trace of the Serghaya fault [4]. Of the 34 large stream valleys of second order or greater observed in the DEM and remote sensing imagery, 32 depict clear leftward deflections. The largest deflections of $6-7 \mathrm{~km}$ can be observed in at least 4 drainages incised into the lowrelief surface atop the Anti Lebanon (Figures 3 and 9). Hence, we interpret these consistent, large deflections to be true displacements. Assuming a late Tortonian-Messinian age (5.5 - 8 $\mathrm{Ma}$ ) is appropriate for the paleo-surface [9, 28], this suggests a minimum long-term slip rate of more than $1 \mathrm{~mm} / \mathrm{yr}$., which is comparable to the $\sim 1.4 \mathrm{~mm} / \mathrm{yr}$. rate of left-lateral slip along the Serghaya fault during the Holocene [1]. Continuing NNE through the northern Anti Lebanon, the morphological expression of the Serghaya fault becomes muted north of the village of Aarsal (Figure 3). 
We interpret the overall geometry of the Serghaya, Rachaya, and (if active) Hasbaya faults is that of a strike-slip duplex [45]. This geometry of left-lateral strike-slip faults involves counter-clockwise rotations of the intervening blocks as a mechanism for partial accommodation of the transpression [46]. Published paleomagnetic results report counter-clockwise rotations of up to 65 degrees [47] in the vicinity of Mt. Hermon. The ends of irregularly shaped, rotating blocks can also cause local shortening or extension, which can produce both the folding and uplift of Mt. Hermon and the opening of the Zebadani Valley, respectively. Strike-slip duplexes involving multiple fault branches may be more appropriate structural models for the Lebanese restraining bend than previous rotating "bookshelf” models involving only one primary strikeslip fault $[47,48]$. The multiple fault splays in the southern Anti Lebanon probably accommodate some of the expected shortening within the Lebanese restraining bend through block rotations.

\subsection{Strike-slip faulting along the northern Dead Sea fault system}

Long-term strike-slip displacements have been difficult to quantify on the northern DSFS, owing to a general lack of appropriate features that serve as piercing points. Some previous workers have suggested that an apparent displacement of the Pliocene "Homs" basalt flow is one possible marker of $10 \mathrm{~km}$ of left-lateral offset $[5,10]$. However, others have argued that this may be at least partially a result of erosion and paleo-topography [6, 28].

Instead of interpreting strike-slip displacement of the lava field, we interpret left-lateral faulting of the volcanic center (Jebel Barshin) within the lava field northwest of Homs (Figures 5 and 11). We believe that the enhanced SAR backscatter image, in combination with the DEM, allows the precise mapping of the outline of the elliptical volcano. The radial drainages and topographic contours depict the elliptical shape (with major axis trending NNW-SSE) of the extinct volcano. The SAR backscatter imagery demonstrates a distinctly less reflective (i.e., darker) texture for the extinct volcano, compared with the surrounding lava flows and outcrop geology (Figure 13). The volcano is less reflective than the surrounding lava flow, perhaps owing to ongoing cultivation of the latter, which increases surface reflectivity. In this SAR image, brightness values have been normalized to remove effects of local incidence angle (owing to local topography) on pixel brightness - thus, backscatter more accurately reflects physical properties of the surface. 
Topographically, Jebel Barshin has an elliptical outline with its long axis oriented NWSE. The peak of the volcano rests at an altitude of approximately $1000 \mathrm{~m}$. Despite Quaternary fluvial incision, the constant slope along the volcano's long axis is evident in topographic profile (Figure 14). The topographic profile is truncated when the long axis obliquely intersects the DSFS.

Although lava flows are found at the highest altitudes (> 1200 meters) in most locations, these correspond with greater structural relief and bedrock dips of 15 to 20 degrees westward. Hence, the positions of these lava flows are more the likely results of topographic uplift, rather than topographic remnants of the Jebel Barshin volcano. Adjacent to the Homs Gap (and corresponding with the region of low radar reflectivity), basalt caps the tops of hills with shallow dipping ( $\sim$ degree dip westward) bedrock beneath. Considering the distance of these hilltop lavas relative to the DSFS, the 800 meter altitude of these lava flows is consistent with the extrapolation of the profile (Figure 14) $5 \mathrm{~km}$ NW of the DSFS. Hence, we suggest that these may represent relict constructional topography of the Jebel Barshin volcano.

This map pattern suggests that the Barshin volcano may be truncated and offset by the northern DSFS (Figures 5 and 11). The volcano’s elliptical outline appears to be left-laterally offset 15 - $20 \mathrm{~km}$. The Homs basalt and Barshin volcano have been dated 5.0 - 5.5 Ma [27, 28], suggesting a minimum long-term slip rate of $3.3-4 \mathrm{~mm} / \mathrm{yr}$. This Pliocene-Quaternary minimum rate is slightly less than, but comparable to, the late Holocene slip rate of $\sim 6.5 \mathrm{~mm} / \mathrm{yr}$. reported by Meghraoui et al. [2].

\section{Contemporaneous uplift and strike-slip in a regional context}

The above observations indicate contemporaneous, Late Cenozoic uplift and strike-slip tectonics for the northern DSFS. It appears that kinematic variations along the northern DSFS probably reflect geometrical variations in the structure of the plate boundary and do not necessarily require temporal changes in plate motions as suggested by some [28]. The geometrical changes correspond with two factors: (1) restraining (e.g., Lebanese Restraining Bend) and releasing (e.g., the Ghab Valley) bends and steps within the transform system, and (2) the transform does not follow a small circle about the pole of the African-Arabian plate motion. Figure 15 illustrates how the geometry of the fault system and the predicted plate motion (based on [11]) result in a general northward increase in both the rate of plate motion and the amount of 
convergence between Africa and Arabia. Hence, the northern DSFS could be viewed as an overall transpressional plate boundary (i.e., obliquely convergent), rather than the classical “leaky” transform [49].

Within the Lebanese Restraining Bend of the DSFS, there is evidence for Late Cenozoic uplift of the Mount Lebanon and Anti Lebanon ranges, as well as the Palmyride fold belt. This uplift occurs in addition to strike-slip displacement on multiple fault branches within the Lebanese restraining bend. These observations do not demonstrate when these structures originated, but they show that they have been active through the Late Cenozoic, and this is consistent with the kinematics of a large restraining bend. Strike-slip movements along this portion of the DSFS did not cease in the late Neogene as suggested by others $[6,28]$.

The expected horizontal shortening within the Lebanese restraining bend appears to be accommodated by several means. The young, small folds and the major anticlinoria are subparallel to the strike of the Yammouneh fault (Figure 2). Structural analyses [20, 28] suggest that these folds have not experienced significant rotations since they contracted. These "in-line" folds thus suggest that oblique motion of Arabia relative to Africa within the Lebanese restraining bend is accommodated by regional strain partitioning $[1,20]$. Following our previously described strain partitioning model [1], some type of kinematic linkage is required between the strike-slip and orthogonal shortening. We suggest that these may be found in the Roum and Akkar faults, which strike obliquely to the other structures of the Lebanese Restraining Bend. More importantly, the Roum and Akkar faults bound the uplifted Mt. Lebanon, and they do not appear to extend beyond the Mount Lebanon. Hence, we suggest that these faults act as "oblique ramp” structures that link the strike-slip kinematics of the Yammouneh fault with the folding and uplift of the Mount Lebanon.

In our new analysis, we suggest that north of the Lebanese Restraining Bend, the increasing plate convergence is primarily responsible for the uplift of the Syrian Coastal Range. Although the Ghab Valley is an extensional basin, we suggest that it represents local extension, rather than characterizing the entire section of the transform. The length of the Syrian Coastal Range is greater than the Ghab Valley, suggesting that uplift of the Syrian Coastal Range is not solely an isostatic response to the local extension and opening of the Ghab valley [26]. The Ghab Valley, may be viewed as a large analog to pull-apart basins that develop along the San Andreas fault within the greater transpressional context of the California Coast Range. The 
linear trace of the DSFS suggests a sub-vertical fault zone, which cannot geometrically accommodate the predicted convergence. Hence, we suggest that a regional partitioning of displacement may also be occurring between the strike-slip faulting and the tilting of the Syrian Coastal Range, perhaps accommodated by blind or offshore structures.

Uplift is asymmetrically distributed along the central and northern DSFS: Uplift of the late Neogene paleo-surface, as well as topography, is greater on the west side of the DSFS than to the east. One possible explanation for this asymmetry may relate to the fact that the western side of the DSFS (i.e., the African plate) involves the Neo-Tethyan rifted continental margin. Hence, the crust of the African plate may be weaker (i.e., inherited faults) reflecting the earlier rifting history of this margin during the Permian [26].

\section{Conclusions}

Integrating a new, high resolution DEM with other high resolution satellite imagery has provided a new view of the large-scale neotectonic features along the northern Dead Sea fault system (DSFS) in Lebanon and Syria. These results indicate strike-slip movements along the northern DSFS during the Pliocene and Quaternary, as well as Late Cenozoic uplift. These kinematics demonstrate regional strain partitioning of oblique plate motions within the Lebanese Restraining Bend, and along the transform to the north. Uplift within the Lebanese Restraining Bend results primarily from the geometrical variations of the restraining bend. Additionally, some of the Late Cenozoic shortening has been accommodated in the western Palmyride fold belt, and this may be kinematically linked with the Serghaya and Jhar faults. Uplift north of the restraining bend probably reflects a northward increase in the amount of convergence between the Arabian and African plates - hence the transform becomes a zone of oblique convergence, rather than a "leaky" transform. In terms of the regional plate tectonic framework, these results indicate that the northern DSFS has been the active plate boundary from the late Cenozoic through the present-day. These results also underscore the importance of considering the possible role of dip-slip faulting and related uplift for regional earthquake hazard assessment, in addition to strike-slip faulting. 


\section{Acknowledgements}

We benefited from helpful discussions with Greg Hoke, Bryan Isacks, and Eric Sandvol. ERS 1 and ERS 2 data were provided by the European Space Agency under data grant AO3-168. Jennifer Yu and Douglas Alsdorf provided assistance with initial InSAR data processing. This research was partially supported by NSF grant EAR-0106238. The field work associated with this study benefited from significant logistical support provided by the Lebanese National Center for Remote Sensing and the Syrian Higher Institute of Applied Sciences and Technology. We also thank A. R. Elias, B. C. Burchfiel, and K. Whipple for helpful reviews of the manuscript. 


\section{References}

[1] F. Gomez, M. Meghraoui, A.N. Darkal, F. Hiajzi, M. Mouty, Y. Suleiman, R. Sbeinati, R. Darawcheh, R. Al-Ghazzi and M. Barazangi, Holocene faulting and earthquake recurrence along the Serghaya branch of the Dead Sea fault system in Syria and Lebanon, Geophysical Journal International 153(3), 658-674, 2003.

[2] M. Meghraoui, F. Gomez, R. Sbeinati, J.V.d. Woerd, M. Mouty, A.N. Darkal, Y. Radwan, I. Layyous, H.A. Najjar, R. Darawcheh, F. Hijazi, R. Al-Ghazzi and M. Barazangi, Evidence for 830 years of Seismic Quiescence from Paleoseismology, Archeoseismology and Historical Seismicity Along the Dead Sea Fault in Syria, Earth and Planetary Science Letters 210, 35-52, 2003.

[3] M. Daeron, L. Benedetti, P. Tapponnier, A. Sursock and R.C. Finkel, Constraints on the post 25-ka slip rate of the Yammouneh fault (Lebanon) using in situ cosmogenic 36Cl dating of offset limestone-clast fans, Earth and Planetary Science Letters 227, 105-119, 2004.

[4] F. Gomez, M. Meghraoui, A.N. Darkal, C. Tabet, M. Khawlie, K. Khair, R. Sbeinati, R. Darawcheh, K. Khair and M. Barazangi, Coseismic displacements along the Serghaya fault: An active branch of the Dead Sea fault system in Syria and Lebanon, Journal of the Geological Society (London) 158, 405-408, 2001.

[5] V.G. Trifonov, V.M. Trubikhin, Z. Adzhamyan, S. Dshallad, Y. El-Khair and K. Ayed, Levant fault zone in northwest syria, Geotectonics 25(2), 145-154, 1991.

[6] R.W.H. Butler, S. Spencer and H.M. Griffiths, Transcurrent fault activity on the Dead Sea Transform in Lebanon and its implications for plate tectonics and seismic hazard, Journal of the Geological Society (London) 154, 757-760, 1997.

[7] R.W. Girdler, The Dead Sea transform fault system, Tectonophysics 180, 1-13, 1990.

[8] Z.R. Beydoun, Evolution and development of the Levant (Dead Sea Rift) Transform System: A historical-chronological review of a structural controversy, in: Continental Tectonics, C. MacNiocaill and P.D. Ryan, eds. 164, pp. 239-255, Geological Society of London, London, 1999. 
[9] A.M. Quennell, The Western Arabia rift system, in: The Geological Evolution of the Eastern Mediterranean, J.E. Dixon and A.H.F. Robertson, eds., pp. 775-788, Blackwell Scientific, Oxford, 1984.

[10] Z. Garfunkel, I. Zak and R. Freund, Active faulting in the Dead Sea rift, Tectonophysics 80, 1-26, 1981.

[11] S. McClusky, R. Reilinger, S. Mahmoud, D.B. Sari and A. Tealeb, GPS constraints on Africa (Nubia) and Arabia plate motions, Geophysical Journal International 155, 126-138, 2003.

[12] S. Joffe and Z. Garfunkel, Plate kinematics of the circum Red Sea -- a re-evaluation, Tectonophysics 141, 5-22, 1987.

[13] F. Jestin, P. Huchon and J.M. Gaulier, The Somalia plate and the Eastern Africa Rift System: present-day kinematics, Geophysical Journal International 116, 637-654, 1994.

[14] Y. Klinger, J.P. Avouac, N. Abou Karaki, L. Dorbath, L. Bourles and J. Reys, Slip rate on the Dead Sea transform fault in the northern Araba Valley (Jordan), Geophysical Journal International 142(3), 755-768, 2000.

[15] M.R. Hempton, Consrtaints on Arbaian plate motion and extensional history of the Red Sea, Tectonics 6(6), 687-705, 1987.

[16] R. Freund, Z. Garfunkel, I. Zak, M. Goldberg, T. Weissbrod and B. Derin, The shear along the Dead Sea rift, Philosophical Transactions of the Royal Society of London, Series A 267(1181), 107-130, 1970.

[17] T.A. Chaimov, M. barazangi, D. Al-Saad, T. Sawaf and A. Gebran, Mesozoic and Cenozoic deformation inferred from seismic stratigraphy in the southwestern intracontinental Palmyride fold-thrust belt, Syria, Geological Society of America Bulletin 104, 704-715, 1992.

[18] T.A. Chaimov, M. Barazangi, D. Al-Saad, T. Sawaf and A. Gebran, Crustal shortening in the Palmyride fold belt, Syria, and implications for movement along the Dead Sea fault system, Tectonics 9(6), 1369-1386, 1990.

[19] C.D. Walley, A braided strike-slip model for the northern continuation of the Dead Sea Fault and its implications for Levantine tectonics, Tectonophysics 145(1-2), 63-72, 1988. 
[20] H.M. Griffiths, R.A. Clark, K.M. Thorp and S. Spencer, Strain accommodation at the lateral margin of an active transpressive zone: geological and seismological evidence from the Lebanese restraining bend, Journal of the Geological Society (London) 157, 289-302, 2000.

[21] L. Dubertret, Carte Geologique du Liban, Lebanese Ministry of Public Works, 1955.

[22] T. Sawaf, G. Brew, R. Litak and M. Barazangi, Geologic evolution of the intraplate Palmyride basin and Euphrates fault system, Syria, in: Peri-Tethys Memoir 6: Peri-Tethyan Rift/Wrench Basins and Passive Margins, P.A. Ziegler, W. Cavazza, A.H.F. Robertson and S. Crasquin-Soleau, eds., Memoire de la Musee Nationale de Histoire Naturelle 186, pp. 441-467, Paris, 2001.

[23] M.P. Searle, Structure of the intraplate eastern Palmyride Fold Belt, Syria, Geological Society of America Bulletin 106(10), 1332-1350, 1994.

[24] V.P. Ponikarov, Geological Map of Syria, Ministry of Industry, Damascus, Syrian Arab Rebublic, 1964.

[25] G. Brew, M. Barazangi, A.K. Al-Maleh and T. Sawaf, Tectonic and geologic evolution of Syria, GeoArabia 6(4), 573-616, 2001.

[26] G. Brew, J. Lupa, M. Barazangi, T. Sawaf, A. Al-Imam and T. Zaza, Structure and tectonic development of the Ghab basin and the Dead Sea fault system, Syria, Journal of the Geological Society (London) 158(4), 665-674, 2001.

[27] M. Mouty, M. Delaloye, D. Fontignie, O. Piskin and J.-J. Wagner, The volcanic activity in Syria and Lebanon between Jurassic and Actual, Schweizerische Mineralogische und Petrographische Mitteilungen 72(1), 91-105, 1992.

[28] R.W.H. Butler, S. Spencer and H.M. Griffiths, The structural response to evolving plate kinematics during transpression: evolution of the Lebanese restraining bend of the Dead Sea Transform, in: Continental Transpressional and Transtensional Tectonics, R.E. Holdsworth, R.A. Strahan and J.F. Dewey, eds., Special Publications 135, pp. 81-106, Geological Society (London), London, 1998.

[29] R.G. Stearns, Warping on the Westenr Highland Rim Peneplain in Tennesse by groundwater sapping, Geological Society of America Bulletin 78, 1111-1124, 1967.

[30] R. Burgmann, R. Arrowsmith, T. Dumitru and R. McLaughlin, Rise and fall of the southern Santa Cruz Mountains, California, from fission tracks, geomorphology, and geodesy, Journal of Geophysical Research 99, 20181-20202, 1994. 
[31] A.E. Blythe, D.W. Burbank, K.A. Farley and E.J. Fielding, Structural and topographic evolution of the central Transverse Ranges, California from apatite fission-track, (UTH)/He and digital elevation model analysis, Basin Research 12, 97-114, 2000.

[32] L.M. Schoenbohm, K.X. Whipple, B.C. Burchfiel and L. Chen, Geomorphic constraints on surface uplift, exhumation, and plateau growth in the Red River region, Yunnan Province, China, Geological Society of America Bulletin 116, 895-909, 2004.

[33] J.A. Spotila, K.A. Farley and K. Sieh, Uplift and erosion of the San Bernardino Mountains associated with transpression along the San Andreas fault, California, as constrained by radiogenic helium thermochronometry, Tectonics 17, 360-378, 1998.

[34] B. Deffontaines, P. Chotin, L.A. Brahim and M. Rozanov, Investigation of active faults in Morocco using morphometric methods and drainage pattern analysis, Geologische Rundschau 81/1, 199-210, 1992.

[35] A.J. Pannekoek, Generalized contour maps, summit level maps, and streamline surface maps a geomorphological tools, Zeitschrift fuer Geomorphologie 11, 169-182, 1967.

[36] A.M. Quennell, The structural and geomorphic evolution of the dead sea rift, Quarterly Journal of the Geological Society (London) 64, 1-24, 1958.

[37] R. Bowen and U. Jux, Afro-Arabian Geology, 250 pp., Chapman and Hall, London, 1987.

[38] E.A. Keller, L. Gurrola and T.E. Tierney, Geomorhpic criteria to determine direction of lateral propagation of reverse faulting and folding, Geology 27, 515-518, 1999.

[39] C.D. Walley, Some outstanding issues in the geology of Lebanon and their importance in the tectonic evolution of the Levantine region, Tectonophysics 298, 37-62, 1998.

[40] P. Sanlaville, R. Dalongeville, P. Bernier and J. Evin, The Syrian coast: A model of Holocene coastal evolution, Journal of Coastal Research 13(2), 385-396, 1997.

[41] R. Dalongeville, J. Laborel, P. Pirazzoli, P. Sanlaville, M. Arnold, P. Bernier, J. Evin and L.-F. Montaggioni, Les variations recents de la ligne de rivage sur le littoral Syrien, Quaternaire 4(1), 45-53, 1993.

[42] R. Westaway, Kinematic consistency between the Dead Sea Fault Zone and the Neogene and Quaternary left-lateral faulting in SE Turkey, Tectonophysics 391, 203-237, 2004.

[43] R. Westaway, M. Pringle, S. Yurtmen, T. Demir, D. Bridgland, G. Rowbotham and D. Maddy, Pliocene and Quaternary surface uplift of western Turkey revealed by long-term river terrace sequences, Current Science 5, 1090-1101, 2003. 
[44] D.R. Bridgeland, G. Philip, R. Westaway and M. White, A long Quaternary terrace sequence in the Orontes River valley, Syria: A record of uplift and of human occupation, Current Science 5, 1080-1089, 2003.

[45] N.H. Woodcock and M. Fischer, Strike-slip duplexes, Journal of Structural Geology 8(7), 725-735, 1986.

[46] F. Gomez, R. Allmendinger, M. Barazangi, A. Er-Raji and M. Dahmani, Crustal shortening and vertical strain partitioning in the Middle Atlas Mountains of Morocco, Tectonics 17, 520-533, 1998.

[47] H. Ron, Deformation along the Yamouneh, the restraining bend of the Dead Sea transform: Paleomagnetic data and kinematic implications, Tectonics 6(5), 653-666, 1987.

[48] H. Ron, A. Nur and Y. Eyal, Multiple strike-slip fault sets: A case study from the Dead Sea transform, Tectonics 9(6), 1421-1431, 1990.

[49] Z. Garfunkel, Internal structure of the Dead Sea leaky transform (rift) in relation to plate kinematics, Tectonophysics 80, 81-108, 1981.

[50] L. Dubertret, Carte Geologique du Liban, Syrie et bordure des pays voisins, Museum National D'Histoire Naturelle, Paris, 1962. 


\section{Figure Captions}

Figure 1. Simplified geology map of the northern Dead Sea Fault System (modified from [50]). Abbreviations: $\mathrm{GF}=$ Ghab fault, $\mathrm{YF}=$ Yammouneh fault, $\mathrm{SF}=$ Serghaya fault, $\mathrm{RF}=$ Roum fault, KSF = Kara Su fault, RaF = Rachaya fault, $\mathrm{HF}=$ Hasbaya fault, $\mathrm{AF}=$ Akkar fault, $\mathrm{PFB}=$ Palmyride Fold Belt, ML = Mt. Lebanon, BV = Bekaa Valley, AL = Anti Lebanon, AM = Amanous Mountains, SCR = Syrian Coastal Ranges, GV = Ghab Valley, KSV = Kara Su Valley. Inset: Regional tectonic map of the eastern Mediterranean region.

Figure 2. A. Shaded relief image produced from the 20-meter pixel DEM of the northern DSFS. B. Slope map derived from the DEM. Abbreviations: PFB = Palmyride Fold Belt, ML $=$ Mt. Lebanon, BV = Bekaa Valley, AL = Anti Lebanon, AM = Amanous Mountains, SCR = Syrian Coastal Ranges, GV = Ghab Valley, KSV = Kara Su Valley.

Figure 3. A. Shaded relief and simplified neotectonic interpretation of the central Dead Sea fault system on shaded relief image. Faults: RF = Roum fault, HF = Hasbaya fault, $\mathrm{SF}=$ Serghaya fault, YF = Yammouneh fault, $\mathrm{AF}=$ Akkar fault, JF = Jhar fault. Other labels: $\mathrm{MH}=$ Mt. Hermon, D = Damour. Profiles A-A' and B-B' are shown in Figure 4. B. Topographic residuals calculated from the DEM may represent proxies for total uplift. In addition, the general extents of the low-relief paleo-surface are also shown.

Figure 4. Profiles of the topographic, envelope, and sub-envelope surfaces across the Lebanese restraining bend (central Dead Sea fault system). Profiles show the mean elevation of the three surfaces of a $5 \mathrm{~km}$ wide swatch along the profile line. See Figure 3 for locations. Abbreviations follow from Figure 1. Patterned areas denote inferred paleo-surface discussed in text.

Figure 5. (A) Simplified neotectonic interpretation of the northern DSFS on shaded relief image (see Figure 2 for location). See Figure 3 for an explanation of symbols. (B) Topographic residuals for the northern DSFS calculated from the DEM. (C) Strain ellipse demonstrating the fault and fold orientations for a left-lateral shear couple. Profiles C-C' and D-D' are shown in Figure 6.

Figure 6. Topographic profiles across the northern DSFS demonstrate asymmetric uplift around the DSFS. See Figure 5 for locations. Abbreviations follow from Figure 1 
Figure 7. Geological cross section (based on mapping of [21]) along the western part of profile A-A' in Figure 4.

Figure 8. (A) Simplified geology (from [21]) and (B) topography in the region of Tripoli. The present channel and inferred paleo-channels of the Abu Ali River (labeled 1 - 3) suggest possible northeastward propagation of the Jaouz anticline. See Figure 3 for location.

Figure 9. Shaded topography image of the Damascus region encompassing the Serghaya fault. Large drainage offsets are prominent along the Serghaya fault. Antecedent streams drain from the Anti Lebanon Mountains eastward across Jebel Kassioun (the westernmost fold of the Palmyride Fold Belt), indicating that late Cenozoic uplift and folding of the western Palmyrides postdates the initiation of the last episode of uplift in the Anti Lebanon Mountains. ZV = Zebadani Valley. White arrows denote large stream deflections . See Figure 3 for location.

Figure 10. Simplified geological map of the Jebel Barshin region and surrounding Neogene lava flows. Dashed lines denote principle contours (500 m interval) that outline the general form of the Barshin volcano and the high relief of the Syrian Coastal Range. Geology is simplified from $[21,24]$. See Figure 5 for location.

Figure 11. A. Simplified geological cross section across the central Syrian Coastal Range (based on geological map of [24]). A late Miocene - early Pliocene paleo-surface is preserved beneath remnants of the Pliocene basalt flows, which have been uplifted 500 meters above the same surface east of the Ghab fault (the principal branch of the Dead Sea fault system in this area). B. Photograph of the paleo-surface preserved beneath the Pliocene basalt. The surface locally tilts 20 degrees to the west. Cross section corresponds with location of profile D-D' in Figure 6 - see also Figure 5 for location.

Figure 12. A. Shaded relief of the southern Bekaa Valley. See Figure 3 for location. A, B, C, \& D correspond with offset notched ridges. L corresponds with the Litani river offset by the Yammouneh fault $(\sim 4 \mathrm{~km})$. R1 is the Litani river offset by the Roum fault, and R2 is the Zahrani river offset by the Roum fault. Ra1 - Ra3 denote large deflections along the Rachaya fault. $\mathrm{MD}=$ Merj Depression. B. Photograph of the offset notched ridges, facing WSW.

Figure 13. Three views of the northern DSFS between the Lebanese border and the Ghab Valley: (A) Shaded topography from the DEM, (B) False-Color Landsat Thematic Mapper (TM) 
image (bands 7,4,1), and (C) ERS2 backscatter image. Stream valley deflections are denoted in the northern part of (A) The radar image (C) differentiates the elliptical shape of the Barshin volcano against the surrounding region (the dark, less reflective region). The radar backscatter image (C) has been processed to emphasize areas of low reflectance (i.e., dark regions), including the Barshin volcano. The ellipse and NW-SE axial ridge (denoted as the red line and consistent with the orientation of maximum compressive stress along a N-S striking, left-lateral fault) appear to be offset $15-20 \mathrm{~km}$ along the DSFS. See Figures 5 and 10 for location.

Figure 14. Topographic profile along the long axis of Jebel Barshin. The relict topography of the volcano's surface can be projected (dashed line) across the DSFS to infer the elevation of expected remnants west of the fault. Noting that the volcano consists of low viscosity basalt, the steep, present-day NW flank likely reflects subsequent erosion (and displacement) of the original surface.

Figure 15. Tectonic map of the DSFS with present-day plate motions predicted from a plate model constrained by GPS [11]. Numbers denote the rate of predicted plate motion (mm/yr), and arrows depict the movement of Arabia relative to Africa resolved at the DSFS. This plate model predicts a northward increase in the rate of motion across the DSFS, as well as increasing convergence. Stippled areas indicate regions of crustal shortening in the northwestern part of the Arabian plate. $\mathrm{EAF}=$ East Anatolian fault. 


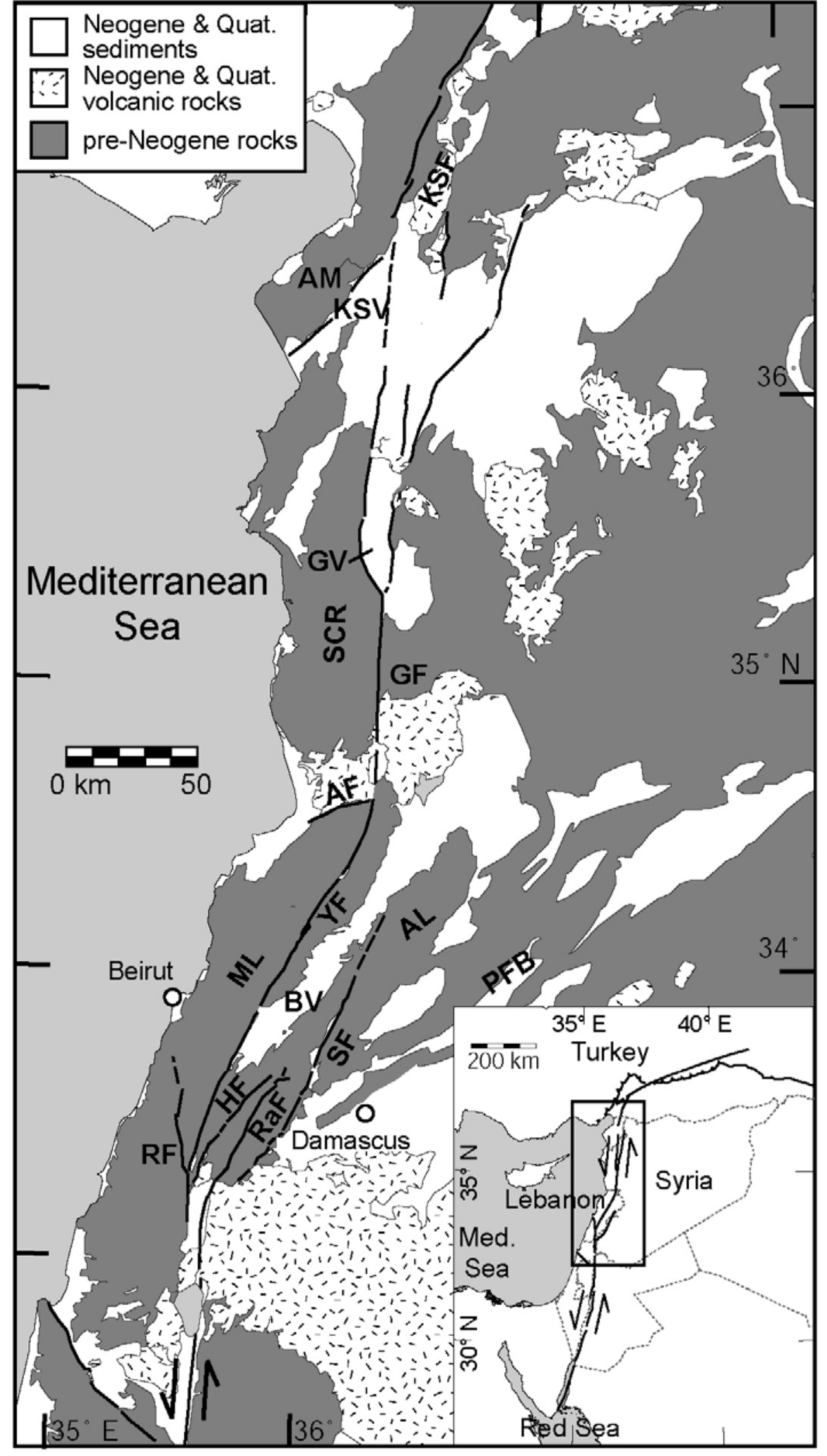

Figure 1 Gomez et al. 

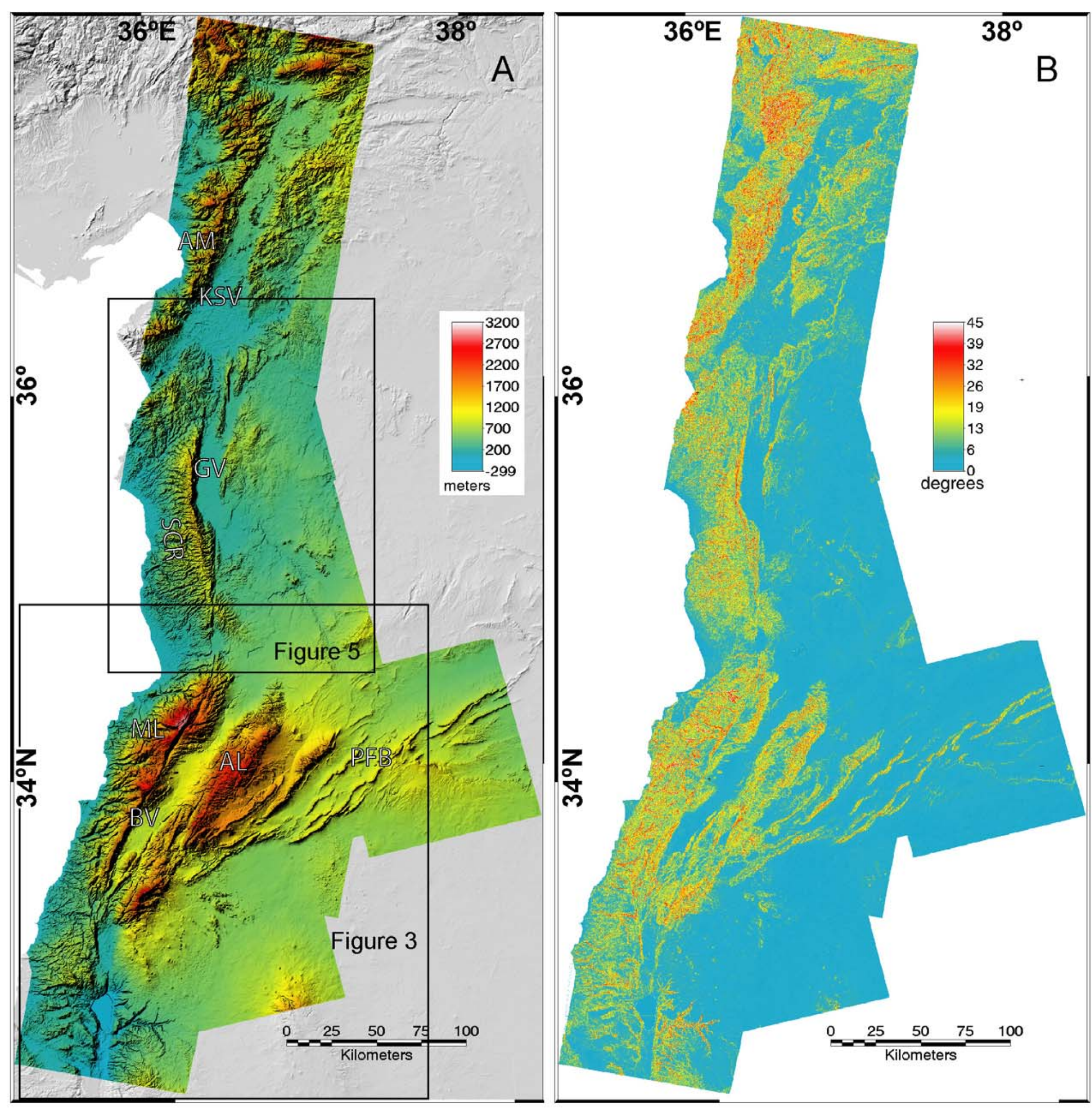

Figure 2 Gomez et al. 

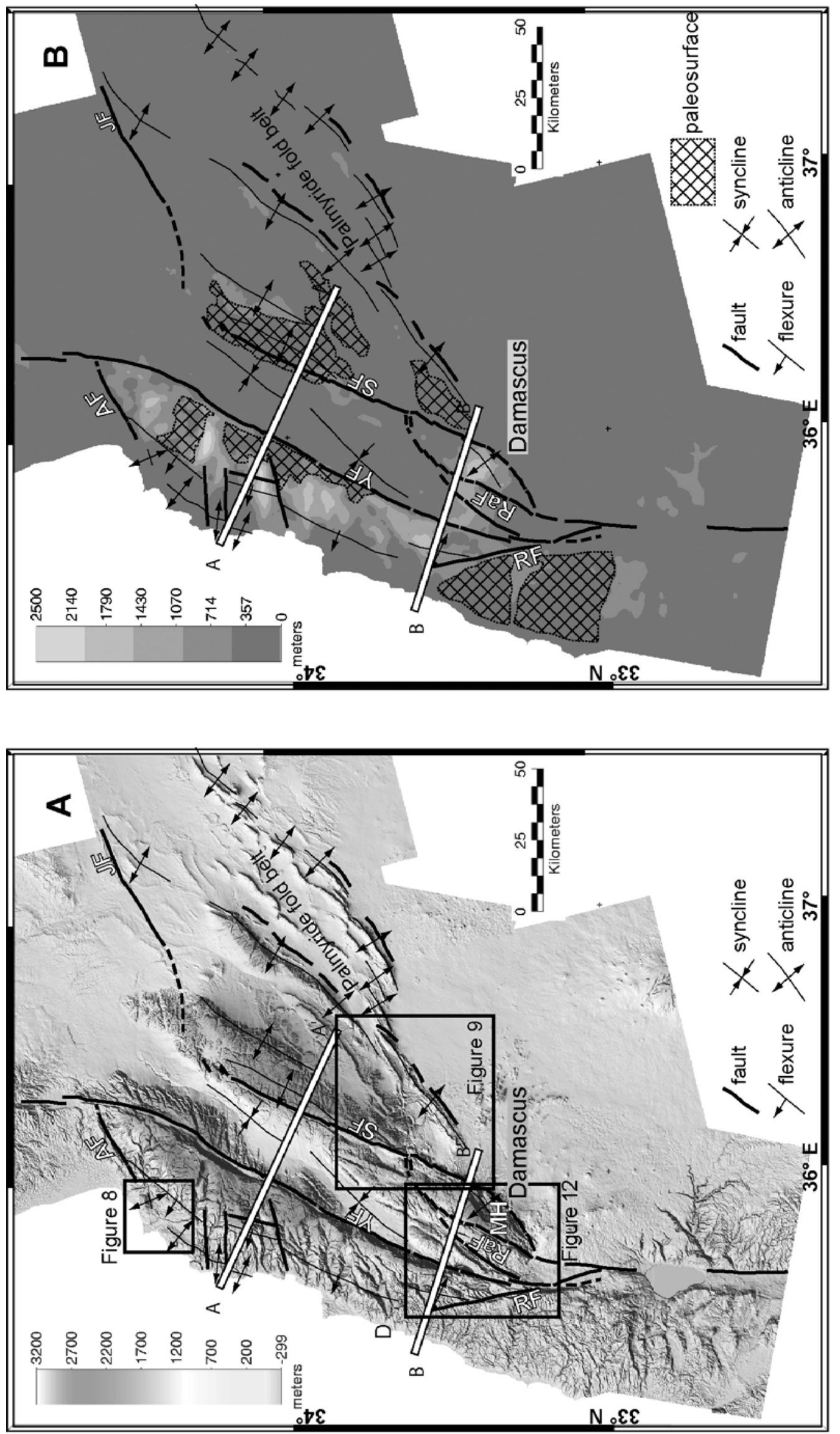

Figure 3 Gomez et al. 

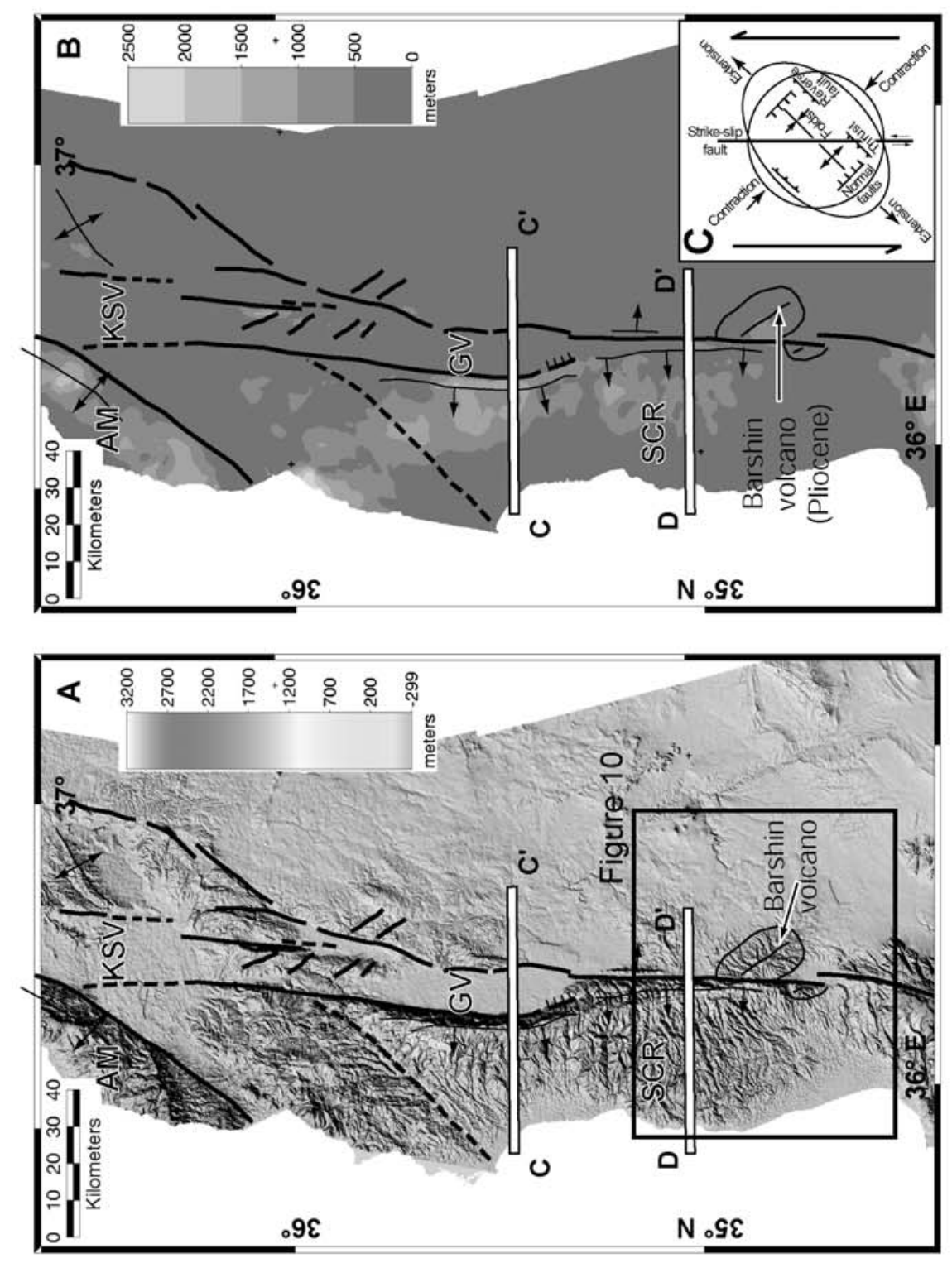


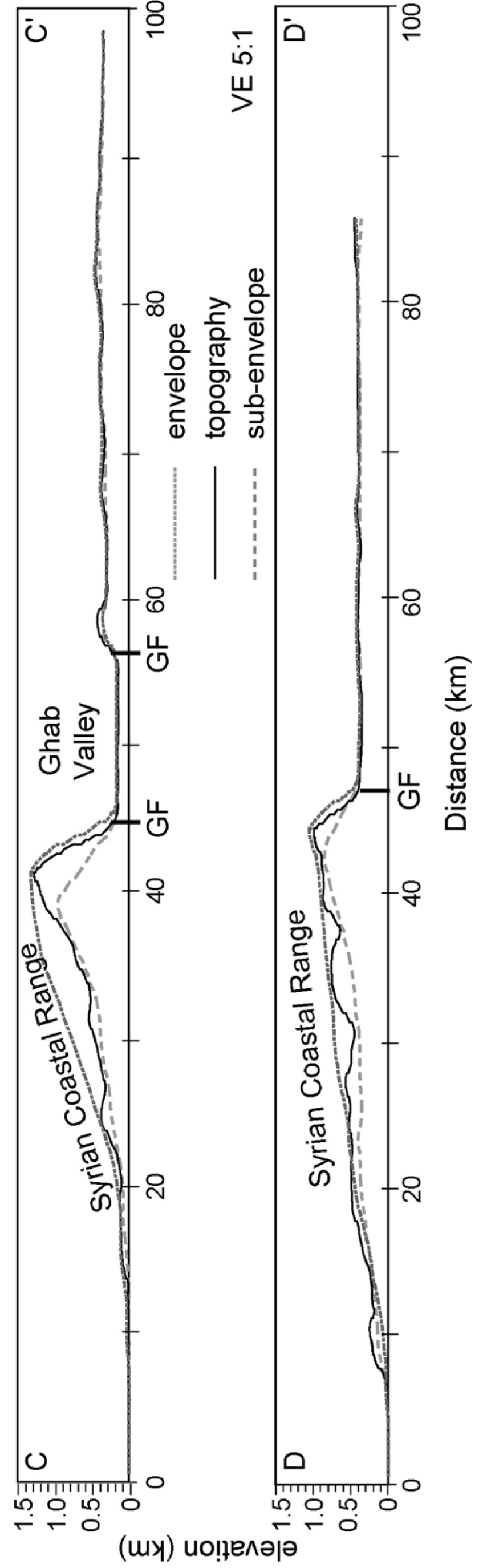

Figure 6 Gomez et al. 


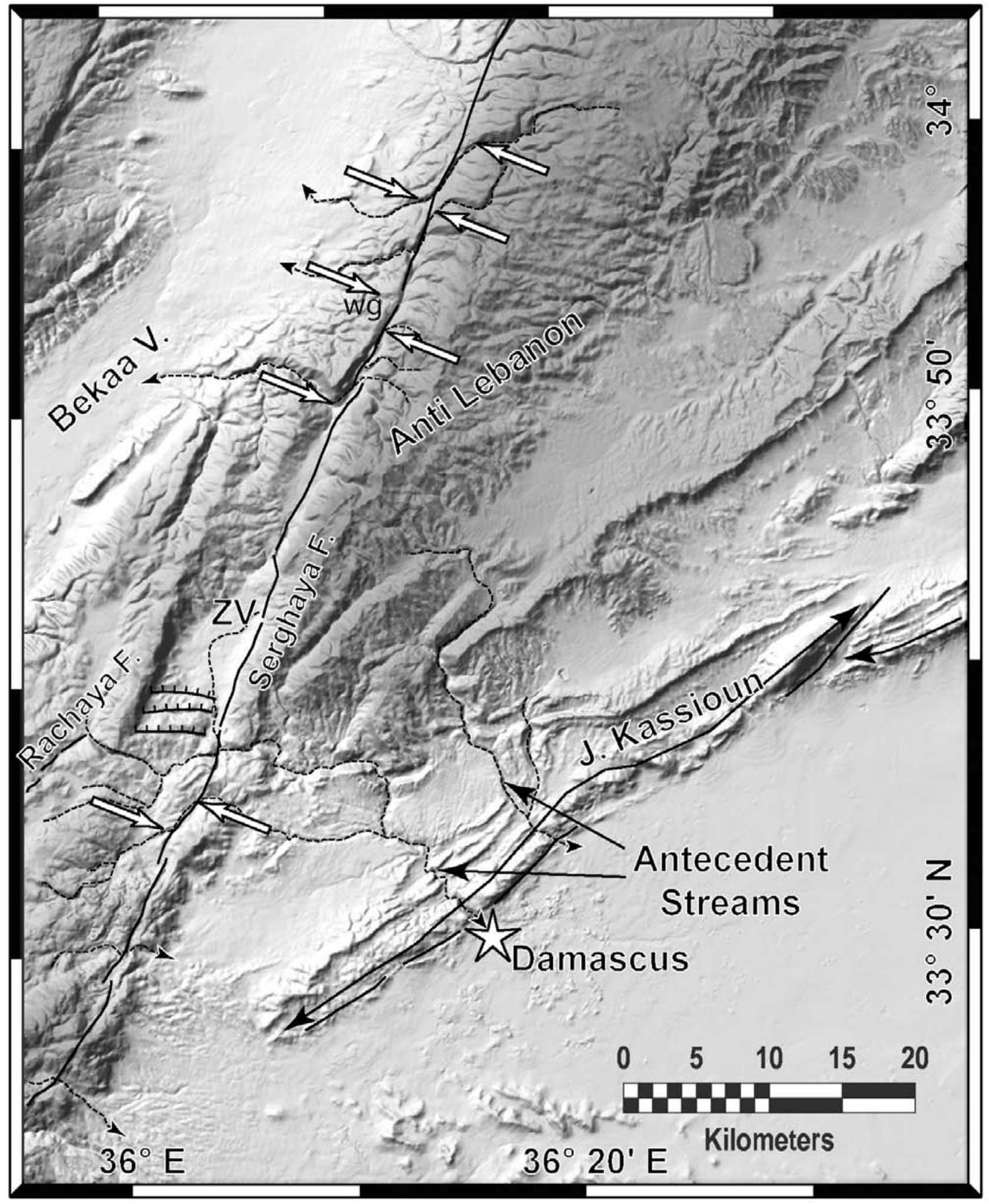

Figure 9 Gomez et al. 


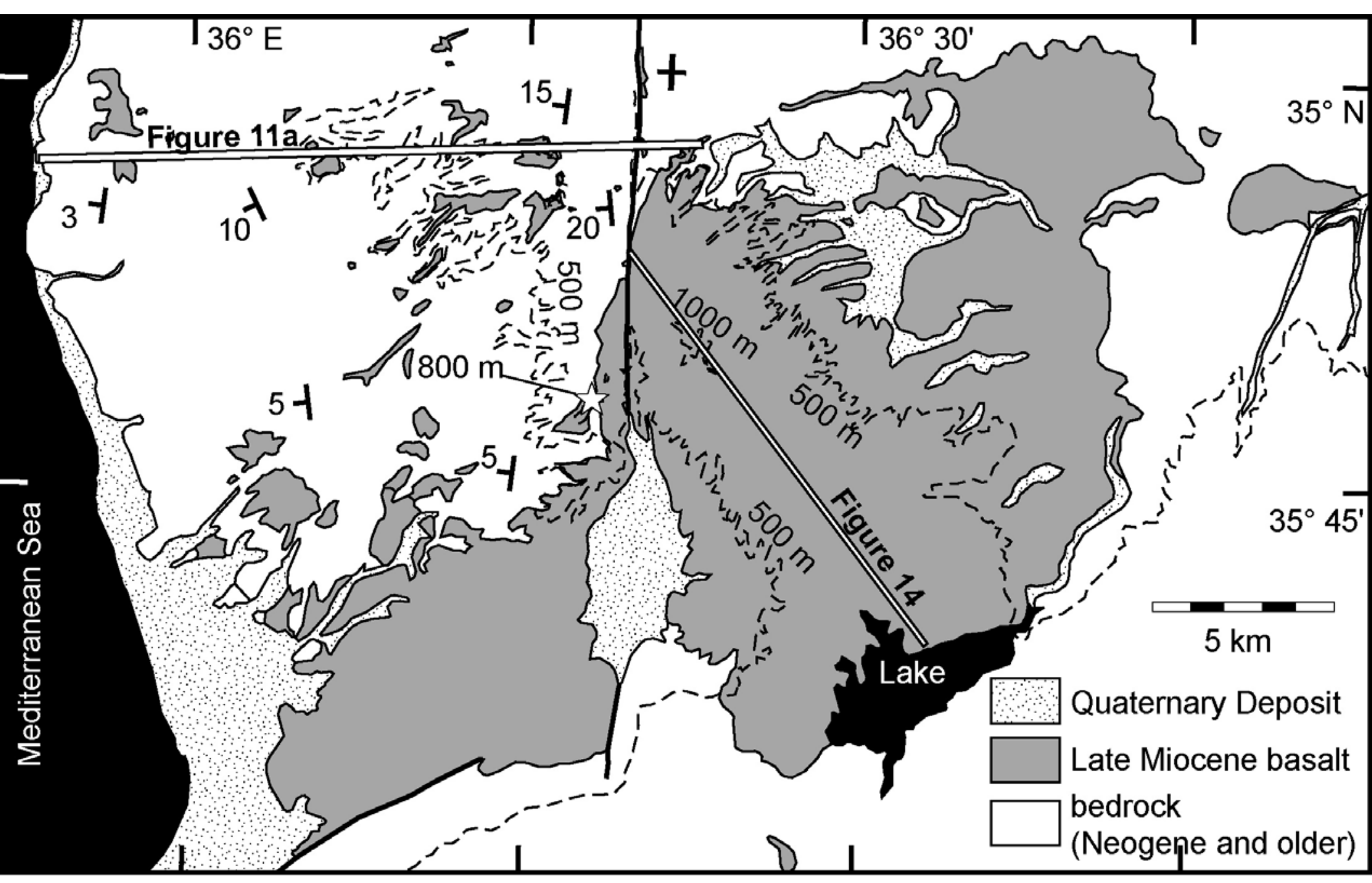

Figure 10 Gomez et al. 


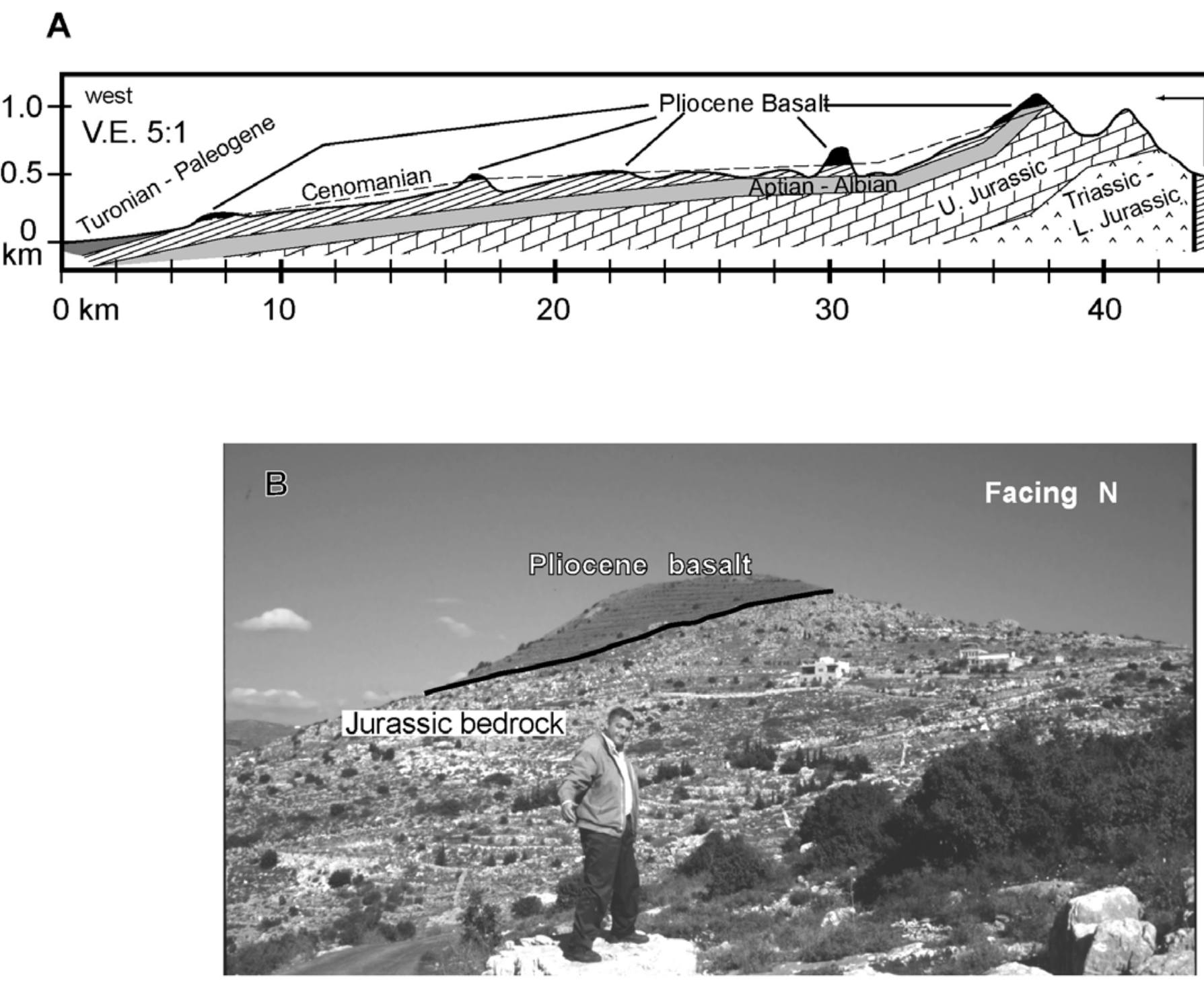

Figure 11 Gomez et al. 

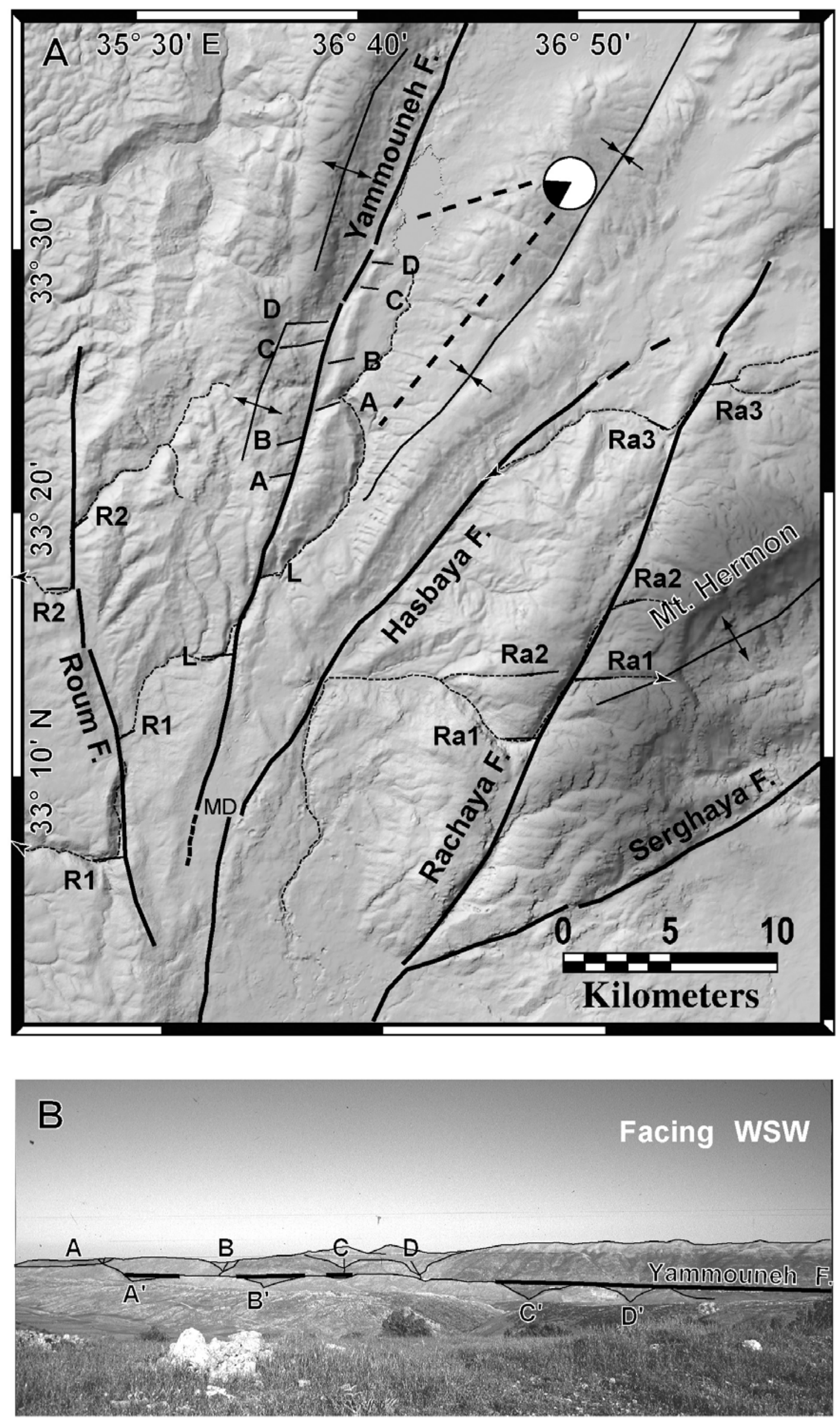

Figure 12 Gomez et al. 

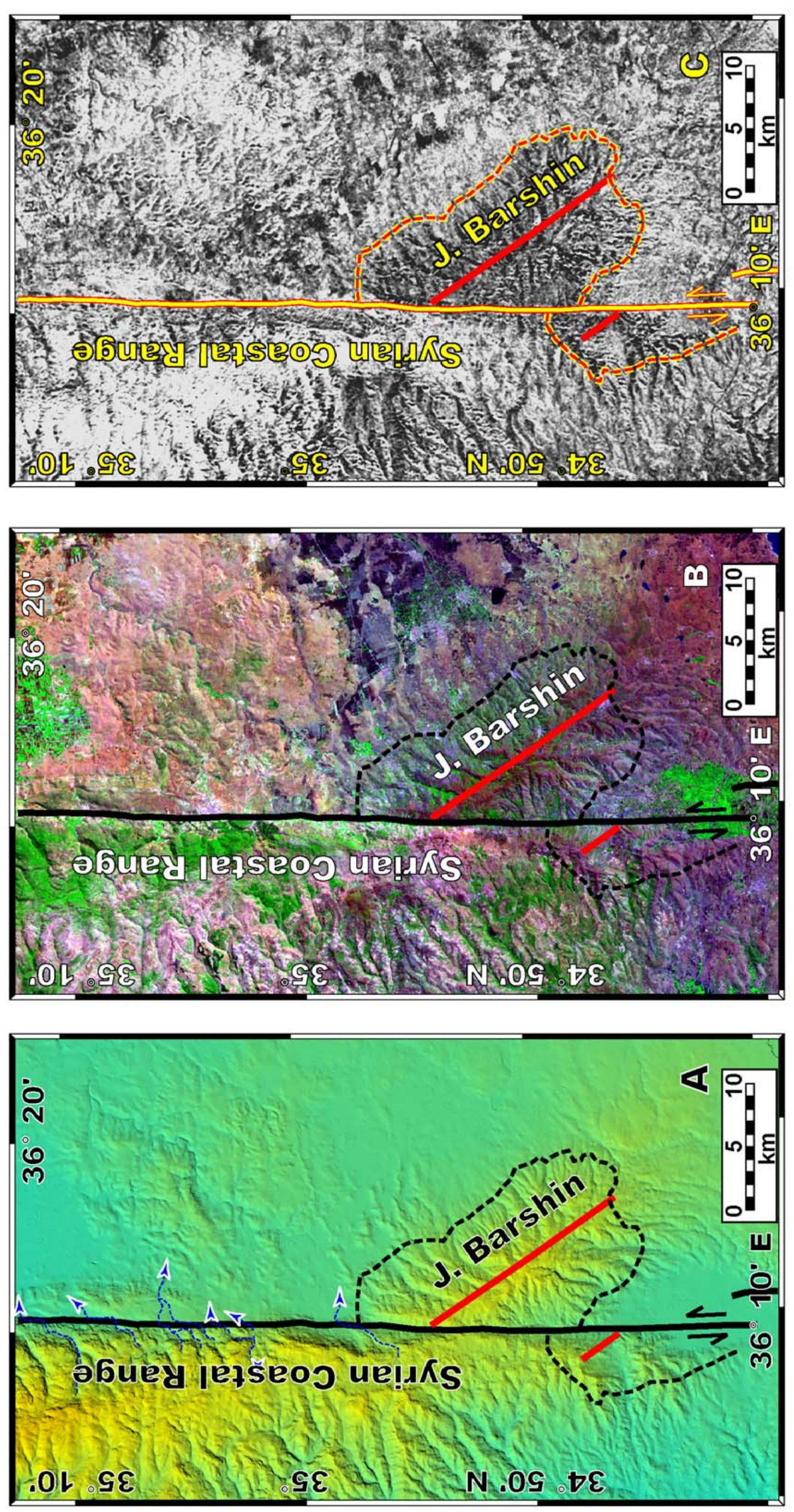

Figure 13 Gomez et al. 
